\title{
Trends in scientific publication on ethnozoology: Brazil's highlight in international science
}

We investigate the trends of the scientific publication on ethno-zoological studies by using the word 'Ethnozoology' in the Web of Science database. We associate the number of published documents with the timescale, publication sources, countries and affiliations, authors, and most frequent words in the publications. We found 177 documents published between 1967 and 2019, with a significant increase over the last 10 years. The Journal of Ethnobiology and Ethnomedicine, Journal of Ethnopharmacology, Indian Journal of Traditional Knowledge hosted 39\% of the publications. Brazil represented by the Universities: Paraíba State, Paraíba Federal and Pernambuco Rural Federal led $44 \%$ of the publications. Alves RRN was the most prominent author, maintaining a high index of publications since 2005 Conservation, animals, knowledge, remedies, fishing communities and folk medicine were the most frequent words in the publications. Despite, ethnozoology to be a traditional science, with more than 50 years since its first published study; Scientific knowledge about ethnozoology has been concentrated in the last 10 years, being mainly developed by Brazilians, who have published in international impact journals. The most relevant words demonstrated that knowledge about the use of animals as fishing resources and folk medicine has major implications for the conservation of biodiversity.

\section{Tendências na publicação científica em etnozoologia: destaque do Brasil na ciência internacional}

\begin{abstract}
Investigamos as tendências da publicação científica sobre estudos etnozoológicos usando a palavra 'Etnozoologia' no banco de dados Web of Science. Associamos o número de documentos publicados à escala de tempo, fontes de publicação, países e afiliações, autores e palavras mais frequentes nas publicações. Encontramos 177 documentos publicados entre 1967 e 2019, com aumento significativo nos últimos 10 anos. The Journal of Ethnobiology and Ethnomedicine, Journal of Ethnopharmacology, Indian Journal of Traditional Knowledge hospedou 39\% das publicações. O Brasil representado pelas Universidades: Paraíba, Paraíba Federal e Pernambuco Rural Federal liderou $44 \%$ das publicações. Alves RRN foi o autor de maior destaque, mantendo um alto índice de publicações desde 2005 . Conservação, animais, conhecimento, remédios, comunidades pesqueiras e medicina popular foram as palavras mais frequentes nas publicações. Apesar disso, a etnozoologia é uma ciência tradicional, com mais de 50 anos desde seu primeiro estudo publicado; 0 conhecimento científico sobre etnozoologia tem se concentrado nos últimos 10 anos, sendo desenvolvido principalmente por brasileiros, que publicam em revistas internacionais de impacto. As palavras mais relevantes demonstraram que o conhecimento sobre o uso de animais como recursos pesqueiros e medicina popular tem grandes implicações para a conservação da biodiversidade.
\end{abstract}

Palavras-chave: Universidade Estadual da Paraíba; Rômulo Romeu Nóbrega Alves; Conhecimento Tradicional; Conservação Animal.

Topic: Planejamento, Gestão e Políticas Públicas Ambientais

Reviewed anonymously in the process of blind peer
Received: 02/01/2021

Approved: 29/01/2021
Aline Mamede Vidica Oliveira (iD

Universidade Estadual de Goiás, Brasil

http://lattes.cnpq.br/6948242682406470

http://orcid.org/0000-0003-0972-8973

alinevidica@yahoo.com.br

Wellington Hannibal Lopes

Universidade Estadual de Goiás, Brasil

http://lattes.cnpq.br/4195742742074059

http://orcid.org/0000-0001-7141-1243

wellingtonhannibal@gmail.com 


\section{INTRODUCTION}

Ethnozoology is an area of science that analyzes the historical and socio-environmental context in the existing relationships between humans and animals (ALVES et al., 2015). This discipline, acts as an instrument to explain the historical relationship between a local population and its fauna, in order to understand human actions and interference in local biodiversity and provide subsidies for conservation (ROCHA-MENDES et al., 2005). Thus, ethno-zoological studies can contribute to knowledge about the impacts of anthropogenic activities on biodiversity. The challenges faced by ethnozoology are evident and numerous, such as improving the efficiency of dialogues between academic areas related to ethnozoology; qualitative advances in research techniques; increased scientific rigidity; improvements in the interaction of knowledge about methodologies and results produced (ALVES et al., 2011). Thus, scientometric studies contribute significantly to guide and fill these gaps, showing the trends and biases in scientific literature about a specific or general discipline

Scientometry use the quantitative analysis of scientific production to seek and demonstrate the trajectory and performance of an area of knowledge (ARAÚJO et al., 2011). Scientometric studies have been investigated trends and gaps in scientific production on different component of biodiversity, with a focus on organisms (e.g. Jatropha curcas L. Euphorbiaceae) (PEREIRA et al., 2018), communities (e.g. plankton community) (SOUZA et al., 2018), biomes (e.g. Cerrado) (BORGES et al., 2015), and mechanisms of ecological processes (e.g. effect of fire in the Cerrado) (ARRUDA et al., 2018). This approach contribute to a better perception of the most relevant points, as well as those of lesser emphasis, providing subsidies for the increase of researches oriented in the possible trends and gaps to be studied in the area (NABOUT et al., 2012).

In this study, we investigate the trends in scientific publication on ethnozoology. For this, we address the following questions: i) Is there a temporal trend in the number of documents published? ii) Which journals have been the main vehicle of publication on this topic? iii) Which countries and affiliations have stood out in scientific production on ethnozoology? iv) Who are the most relevant authors on this discipline? v) Which words appeared most frequently in scientific publications?

\section{MATERIALS AND METHODS}

To answer our questions, we use the word 'Ethnozoology' in the Web of Science (WoS) database, without a defined time-scale. WoS has a worldwide reach, covers different themes of science, and is one of the most used databases in scientometric studies. We consider the following categories that could be associated with the number of documents published: i) year of publication; ii) publication source - journal that published documents; iii) country of origin and affiliation of the corresponding author, and partnership in publications between countries; iv) authors responsible for publications; v) more relevant words, based on the frequency that words appear in publications.

We investigated the pattern in the data distribution through the 'biblioshiny' function of the 
bibliometrix package (ARIA et al., 2017). Graphically, we filter the first 20 results of each evaluated category (source of publication, country of origin and affiliation of the corresponding author, corresponding author of publication), and 50 most prominent words in the studies. To test the association between the number of documents (dependent variable) and the time scale (independent variable), we use Pearson's correlation, function 'cor.test'. All functions and statistical analyzes were performed by the R Program (R CORE TEAM, 2013).

\section{RESULTS}

We found 177 documents ( $n=148$ articles) related to ethnozoology (Supplementary Material 1 ). According to WoS database, the first publication with an ethno-zoological approach occurred in 1967, with a significant increase in the number of documents from 2007 ( $\rho=0.76 ; g l=25 ; p<0.001)$, reaching a maximum of 19 publications in 2016 (Figure 1A). Of the 73 journals that published ethno-zoological studies, Journal of Ethnobiology and Ethnomedicine ( $n=37$ articles), Journal of Ethnopharmacology $(n=20)$ and Indian Journal of Traditional Knowledge ( $n=12$ ) harbor $39 \%$ of the publications (Figure 1B).

\begin{tabular}{|c|c|}
\hline Description & Results \\
\hline Documents & 177 \\
\hline Sources (Journals, Books, etc.) & 73 \\
\hline Keywords Plus (ID) & 466 \\
\hline Author's Keywords (DE) & 471 \\
\hline Period & $1967-2019$ \\
\hline Average citations per documents & 13.42 \\
\hline Authors & 445 \\
\hline Author Appearances & 639 \\
\hline Authors of single-authored documents & 29 \\
\hline Authors of multi-authored documents & 416 \\
\hline Single-authored documents & 35 \\
\hline Documents per Author & 0.398 \\
\hline Authors per Document & 2.51 \\
\hline Co-Authors per Documents & 3.61 \\
\hline Collaboration Index & 2.93 \\
\hline \multicolumn{2}{|l|}{ Document types } \\
\hline ARTICLE & 148 \\
\hline ARTICLE; PROCEEDINGS PAPER & 1 \\
\hline BOOK REVIEW & 4 \\
\hline LETTER & 1 \\
\hline MEETING ABSTRACT & 2 \\
\hline NOTE & 1 \\
\hline REVIEW & 20 \\
\hline
\end{tabular}

Supplementary Material 1: General data result for biblioshiny.

Twenty-five countries had published studies on ethnozoology, highlighting Brazil, with $44 \%$ ( $n=78$ documents) in the world's scientific production (Figure 2A). About Brazilian publication, $87 \%$ were did exclusively by Brazilian scientists, and $13 \%$ in collaboration with scientists in the USA and United Kingdom scientists (Figures 2A and B). Brazilian ethno-zoological production was linked mainly to the Universidade Estadual da Paraíba ( $n=57$ documents), the Universidade Federal da Paraíba $(n=45)$, and the Universidade Federal Rural do Pernambuco ( $n=16$, Figure 2 C). 
A)

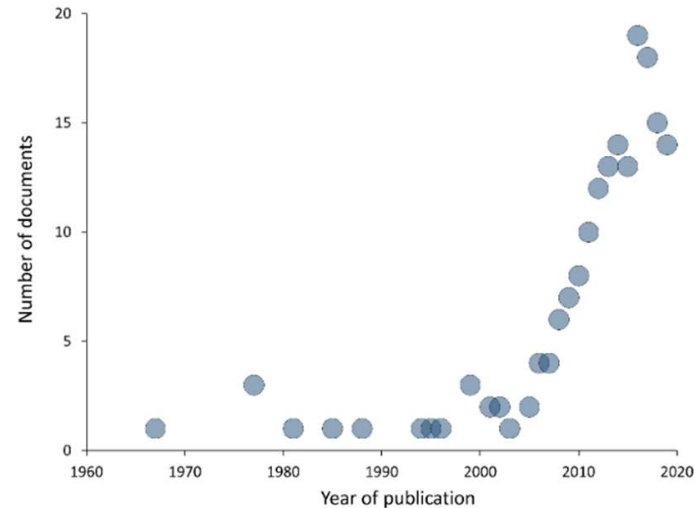

B)

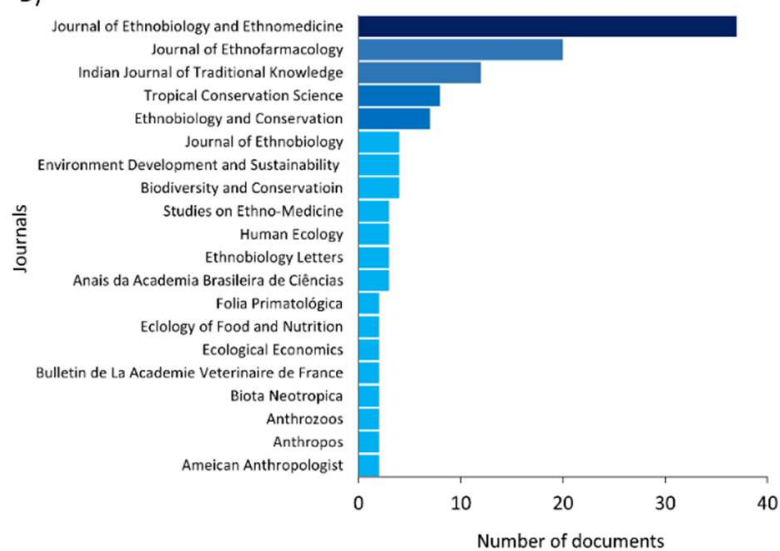

Figure 1: Trends in the number of documents published about ethnozoology related to $A$ ) year of publication and B) journal of publication, according WoS database.

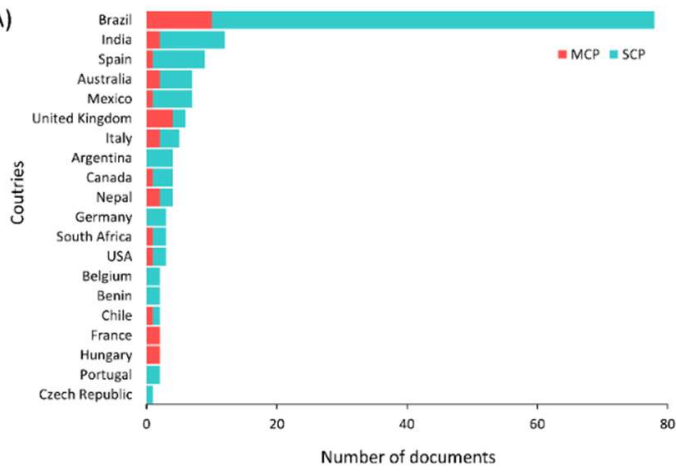

B)
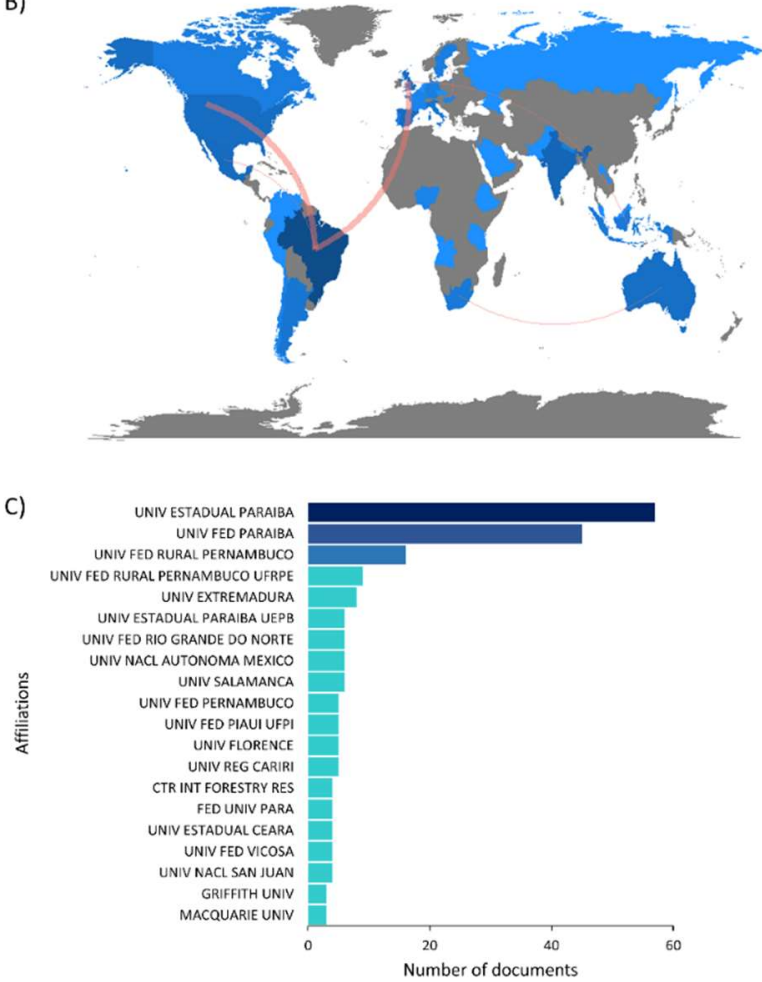

Figure 2: Trends in the number of documents published on ethnozoology according WoS database. A) Country of the corresponding author $(\mathrm{SCP}=$ production within a single country, $\mathrm{MCP}=$ production between multiple countries). B) Collaboration between countries (shades of blue plus dark ones reflect countries with a greater number of publications and thicker lines reflect a greater number of collaborative productions). C) Affiliation of the corresponding author.

A total of 445 authors were responsible for scientific production on ethnozoology, distributed among 29 authors of documents with single authorship, and 416 authors of documents with multiple authorship, resulting in 0.398 documents per author; 2.51 authors per document; 3.61 co-authors per documents (Supplementary Material 1). Of the 20 more relevant authors, the professor Rômulo Romeu Nóbrega Alves were responsible for $28 \%$ of the production about ethnozoology (Figure $3 \mathrm{~A}$ ), and maintenance a high number of publications since the year 2005 (Figure 3B). 

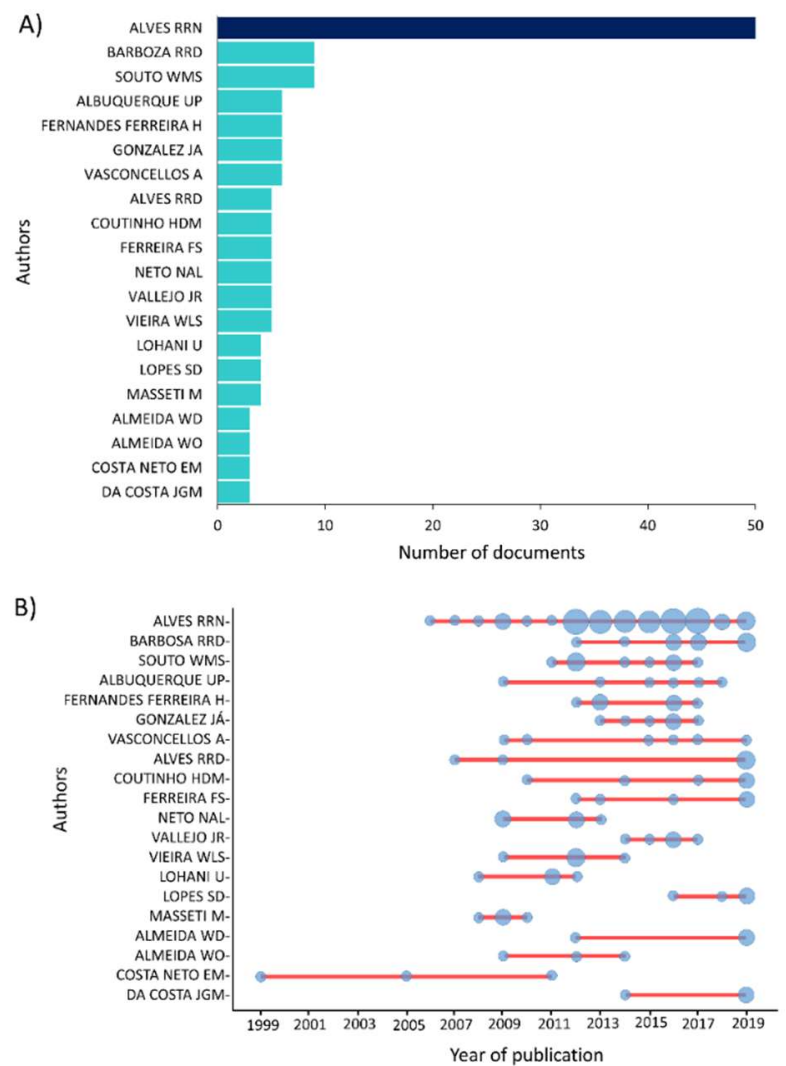

Figure 3: Trends in scientific production on ethnozoology according WoS database. A) Number of documents published by 20 best-ranked authors, B) Author's publications in the last 20 years, circle-size represent percentage of publications.

Of the 466 keywords that appeared in publications on ethnozoology, conservation ( $n=41$ documents), animals $(n=34)$, knowledge $(n=25)$, remedies $(n=20)$, fishing communities $(n=17)$, folk medicine $(n=17)$, management $(n=17)$, plants $(n=15)$, semi-arid region $(n=15)$ and northeastern Brazil $(n$ = 12) were the top-10 (Figure 4).

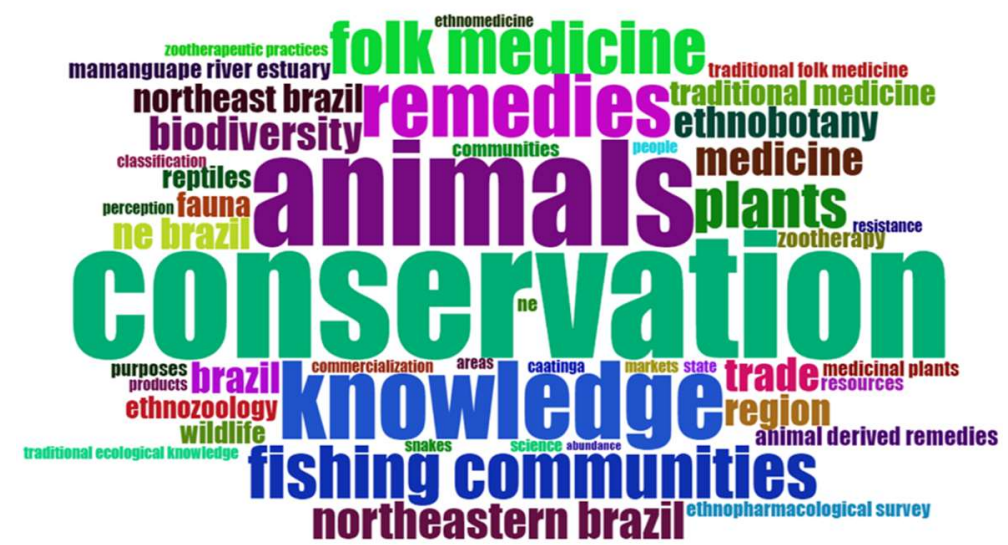

Figure 4: Fifty most frequent keywords in publications on ethnozoology according to Web of Science dabase.

\section{DISCUSSION}

The trends in scientific production showed that the study of ethnozoology has significantly increased in the last 10 years, driven by researchers from the northeast of Brazil, mainly of the Paraíba and Pernambuco 
States, with publications in international journals and focusing on conservation, animals and knowledge. The high number of published articles ( $84 \%$ ) should be associated with the impact of articles on the scientific community, both nationally and internationally. The scientific article is the first step in the generation of knowledge related to the research activity, and the main mode of scientific information (ARAÚJO et al., 2017). Further, Brazilian research foment agencies (e.g. Capes, CNPq) attribute considerable weight to published articles, because, unlike books, there are bibliometric bases and indexers adopted (BRASIL, 2017).

The increase in the number of publications over the years and the high number of Brazilian publications are results of globalization driven by the advanced of networks (e.g. internet), with the development of scientific databases on platforms known worldwide (PITTA et al., 2006). There has also been an increase in the number of journals, institutions, researchers and research centers worldwide, and especially in Brazil, in the last 20 years (SOUZA, 2006). As a result, Brazil has made significant progress in scientific and technological activity (SOARES, 2018). The vast majority of documents published by Brazilians were inserted in international journals, such as Journal of Ethnobiology and Ethnomedicine ${ }^{1}$, Journal of Ethnofarmacology ${ }^{2}$, Indian Journal of Traditional Knowledge ${ }^{3}$. Brazil also stands out in collaboration on ethno-zoological publications with the United Kingdom and the United States of America, enabling a significant exchange regarding the knowledge acquired in the area. Thus, the Brazilian researches about ethnozoology has shown a significant impact at the international science.

The emphasis on the number of publications in the northeastern of Brazil can be associated to the development and growth of the region, as well as to the importance of scientific collaboration networks (SIDONE et al., 2016). However, we highlighted that association between the increase in ethno-zoological studies for Paraíba and Pernambuco states are results of two Brazilian scientists, professor Rômulo Romeu Nóbrega Alves of the Universidade Estadual da Paraíba and professor Ulysses Paulino de Albuquerque of the Universidade Federal de Pernambuco. Professor Rômulo R. N. Alves was corresponding author of 50 publications in the last 15 years; he is a biologist (Ph.D. in Zoology) with a keen interest in the connections between humans and animals. His areas of academic interest are ethnozoology and wildlife trade, uses and conservation, zootherapy, and human ecology. He has conducted ethnobiological research for the last ten years, which focuses on ethnozoology, particularly on fisheries, hunting, and wildlife trade and uses. As result, he published (as author or co-author) 203 scientific papers published in both national and international journals, 13 books and 93 book chapters. Currently, coordinates projects on hunting and uses of wildlife in Brazil. In addition, he is one of the Editors-in-Chief of the journal Ethnobiology and Conservation and member of the Editorial Board of the Journal of Ethnobiology and Ethnomedicine. He hold a Productivity scholarship, provided by the National Council of Science and Technology (CNPq) ${ }^{4}$.

The publications obtained on ethnozoology demonstrate a predominance of the words conservation, animals and knowledge. In addition to hunting for food and subsistence, animals are used as zootherapeutic

\footnotetext{
${ }^{1}$ https://ethnobiomed.biomedcentral.com/

2 https://www.journals.elsevier.com/journal-of-ethnopharmacology

${ }^{3}$ http://nopr.niscair.res.in/

${ }^{4}$ http://lattes.cnpq.br/9947001739918371
} 
products, for rituals and amulets, showing the influence of social, cultural and economic aspects in animalhuman relationship (ALVES et al., 2011). Ethno-zoological researches can assist in the analysis and investigation of the impact that human communities have about animal species, as well as in the expansion of projects aimed at sustainable management (ALVES et al., 2015). For example, tetrapod vertebrates represent a carismatic and threatened group, nevertheless, little studies has been carried about these animals due to legislation restrictions (LYRA-NEVES et al., 2015). In this context, interdisciplinary research is extremely important to support ethno-zoological studies with a conservationist focus (LIMA et al., 2014).

\section{CONCLUSIONS}

We highlight a progress in the study of Ethnozoology in recent years, with scope in international science, and led by researchers from the northeast of Brazil. However, other advances are still necessary for this discipline to establish itself in the international scientific community, such as: a greater insertion of international scientific communities (USA, United Kingdom, Australia, Canada, China) in the study of Ethnozoology. Thus, the trends and gaps found in this study are important for guidance on possible conduct of future work, thus subsidizing preponderant information for scientific advancement.

ACKNOWLEDGEMENTS: We are grateful to the Fundação de Amparo à Pesquisa do Estado de Goiás (FAPEG) for finantial support given to AMVO (Edital 03/2018).

\section{REFERENCES}

ARIA, M.; CUCCURULLO, C.. Bibliometrix: An R-tool for comprehensive Science mapping analysis. Journal of Informetrics, v.11, n.4, p.959-975, 2017.

ALVES, R. R.; SOUTO. W. M.. Ethnozoology: A Brief Introduction. Ethnobiology and Conservation, v.2015, n.4, p.1, 2015. DOI: https://doi.org/10.15451/ec2015-1-4.1-1-13

ALVES, R. R.; SOUTO. W. M.. Ethnozoology in Brazil: current status and perspectives. Journal of Ethnobiology and Ethnomedicine, v.7, n.22, 2011.

ARAÚJO, P. C.; MIGUEL, S.. Motivações dos discentes do Programa de Pós-graduação em Direito da Universidade Federal do Paraná (UFPR) para publicar em periódicos científicos no domínio do Direito. Perspectivas em Ciência da Informação, v.22, n.1, p.38-56, 2017.

ARAÚJO, R. F.; ALVARENGA, L.. A bibliometria na pesquisa científica da pós-graduação brasileira de 1987 a 2007.

Encontros Bibli: Revista Eletrônica de Biblioteconomia e Ciência da Informação, Florianópolis, v.16, n.31, p.51-70, 2011. DOI: http://dx.doi.org/10.5007/15182924.2011v16n31p51

ARRUDA, F. V.; SOUSA, D. G.; TERESA, F. B.; PRADO, V. H. M.; CUNHA, H. F.; IZZO, T. J.. Trends and gaps of the scientific literature about the effect of fire on Brazilian Cerrado. Biota Neotrop.; Campinas, v.18, n.1, 2018.

BORGES, P. P.; OLIVEIRA, K. A. F. A.; MACHADO, K. B.; VAZ,
Ú. L.; CUNHA, H. F.; NABOUT, J. C.. Trends and gaps of the scientific literature on the Cerrado biome: A scientometric analysis. Neotropical Biology and Conservation, v.10, n.1, p.2-8, 2015. DOI: http://doi.org/10.4013/nbc.2015.101.01

BRASIL. Ministério da Educação. Coordenação de Aperfeiçoamento de Pessoal de Nível Superior Diretoria de Avaliação. Considerações sobre Classificação de Livros. Avaliação Quadrienal. Brasília: MEC, 2017.

LIMA, J. R. B.; FLORÊNCIO, R. R.; SANTOS, C. A. B. Contribuições da Etnozoologia para a conservação da Fauna silvestre. Revista Ouricuri, Paulo Afonso, v.4, n.3, p.048-067, 2014.

LYRA-NEVES, R. M.; SANTOS, E. M.; MEDEIROS, P. M.; ALVES, R. R. N.; ALBUQUERQUE, U. P.. Ethnozoology in Brazil: analysis of the methodological risks in published studies. Brazilian Journal of Biology, São Carlos, v.75, n.4, 2015.

NABOUT, J. C.; CARVALHO, P.; PRADO, M. U.; BORGES, P. P.; MACHADO, K. B.; HADDAD, K. B.; MICHELAN, T. S.; CUNHA, H. F.; SOARES, T. N.. Trends and Biases in Global Climate Change Literature. Natureza \& Conservação, v.10, n.1, p.4551, 2012. DOI: http://doi.org/10.4322/natcon.2012.008

PEREIRA, I. R.; D'ABADIA, P. L.; PRADO, A. D. L.; MATOS, F. S;. NABOUT, J. C.; GONÇALVES, P. J.; ALMEIRA, L. M.. Trends and gaps in the global scientific literature about Jatropha curcas L. (Euphorbiaceae), a tropical plant of economic importance. Semina: Ciências Agrárias, v.39, n.1, p.7-18, 
2018. DOI: http://doi.org/10.5433/1679-0359.2018v39n1p7

PITTA, G. B. B.; CASTRO, A. A.. A pesquisa científica. J. Vasc. Brasileiro, v.5, n.4, 2006.

R CORE TEAM. R: a language and environment for statistical computing. Vienna: R Foundation for Statistical Computing, 2013.

ROCHA-MENDES, F.; MIKICH, S. B.; BIANCONI, G. V.; PEDRO, W. A.. Mamíferos do Município de Fénix, Paraná, Brasil: etnozoologia e conservação. Revista Brasileira de Zoologia, v.22, n.4, p.991-1002, 2005.

SIDONE, O. J. G.; HADDAD, E. A.; MENA-CHALCO, J. P.. A ciência nas regiões brasileiras: evolução da produção e das redes de colaboração científica. Trans. Informação,

Campinas, v.28, n.1, p.15-31, 2016. DOI:

https://doi.org/10.1590/2318-08892016002800002

SOARES, P. C.. Contradições na pesquisa e pós-graduação no Brasil. Estudos Avançados, v.32, n.92, p.289-313, 2018.

SOUZA, E. P. S.. Publicações de Revistas científicas na Internet. Revista Brasileira Cir. Cardiovasc., São José do Rio Preto, v.21, n.1, 2006.

SOUZA, C. A.; GOMES, L. F.; NABOUT, J. C.; VELHO, L. F. M.; VIEIRA, L. C. G.. Temporal trends of scientific literature about zooplankton community. Neotropical Biology and Conservation, v.13, n.4, p.274-286, 2018.

A CBPC - Companhia Brasileira de Produção Científica (CNPJ: 11.221.422/0001-03) detém os direitos materiais desta publicação. Os direitos referem-se à publicação do trabalho em qualquer parte do mundo, incluindo os direitos às renovaç̃ões, expansões e disseminações da contribuição, bem como outros direitos subsidiários. Todos os trabalhos publicados eletronicamente poderão posteriormente ser publicados em coletâneas impressas sob coordenação da Sustenere Publishing, da Companhia Brasileira de Produção Científica e seus parceiros autorizados. Os (as) autores (as) preservam os direitos autorais, mas não têm permissão para a publicação da contribuição em outro meio, impresso ou digital, em português ou em tradução. 